\title{
DIGITALCOMMONS

8-1-2012

\section{Genetic Susceptibility To Type 2 Diabetes: A Global Meta-Analysis Studying the Genetic Differences In Tunisian Populations}

Rym Berhouma

Laboratory of Genetics, Immunology and Human Pathologies, Faculty of Sciences of Tunis, University of Tunis El Manar, Tunisia, berhoumar@gmail.com

S. Kouidhi

Laboratory of Genetics, Immunology and Human Pathologies, Faculty of Sciences of Tunis, University of Tunis El Manar, Tunisia

M. Ammar

Laboratory of Genetics, Immunology and Human Pathologies, Faculty of Sciences of Tunis, University of Tunis El Manar, Tunisia

H. Abid

Hospital of Charles Nicolle in Tunis, Tunisia

T. Baroudi

Laboratory of Genetics, Immunology and Human Pathologies, Faculty of Sciences of Tunis, University of Tunis El Manar, Tunisia

\section{Recommended Citation}

Open access pre-print, subsequently published as Berhouma, Rym; Kouidhi, Soumaya; Ammar, Mariem; Abid, Hafawa; Baroudi, Thouraya; Ennafaa, Hajer; and Benammar-Elgaaied, Amel (2012) "Genetic Susceptibility to Type 2 Diabetes: A Global Meta-Analysis Studying the Genetic Differences in Tunisian Populations," Human Biology: Vol. 84: Iss. 4, Article 9.

Available at: http://digitalcommons.wayne.edu/humbiol_preprints/3

This Open Access Preprint is brought to you for free and open access by the WSU Press at DigitalCommons@WayneState. It has been accepted for inclusion in Human Biology Open Access Pre-Prints by an authorized administrator of DigitalCommons@WayneState. 
See next page for additional authors 
Authors

Rym Berhouma, S. Kouidhi, M. Ammar, H. Abid, T. Baroudi, H. Ennafaa, and A. Benammar-Elgaaied 


\title{
TITLE: Genetic susceptibility to type 2 diabetes: a global meta- analysis studying the genetic differences in Tunisian populations
}

\author{
$\underline{\text { R. Berhouma }}^{1}$, S. Kouidhi ${ }^{1}$, M. Ammar ${ }^{1}$, H. Abid ${ }^{2}$, T. Baroudi ${ }^{1}$, H. Ennafaa ${ }^{1}$, A. Benammar-Elgaaied ${ }^{1}$ \\ ${ }^{1}$ : Laboratory of Genetics, Immunology and Human Pathologies, Faculty of Sciences of Tunis. University of \\ Tunis El Manar. Tunisia \\ ${ }^{2}$ : Hospital of Charles Nicolle in Tunis, Tunisia.
}

The article category: original article

Short running title: genetic variants and T2D risk in Tunisian cases

Key words: type 2 diabetes, polymorphism genes, genetic heterogeneity

Corresponding Author: Rym Berhouma

Address: Laboratory of Genetics, Immunology and Human Pathologies.

Faculty of Sciences of Tunis. 2092 Tunis/ Tunisia.

Tel: +216 25450590/ Fax: +216 71885 480/ e-mail: berhoumar@gmail.com 


\section{ABSTRACT}

The present study is the first meta-analysis to evaluate type 2 diabetes (T2D) - associated polymorphisms in cohorts originated from several Tunisian regions. In fact, we evaluated the effect of seven polymorphisms in the following genes ; PPARg ( Pro12Ala), TNFa (-308A/G), ENPP1(K121Q), TCF7L2(rs7903146 C/T), MTHFR( C677T), $A C E(I / D), C A P N 10(3 R / 2 R)$ on T2D risk, through a meta-analysis combining data of previous studies performed on Tunisian populations originating from the north, centre or south of the country. R statistics version 2.12.1 software was used to estimate the heterogeneity between studies. Pooled ORs were computed by the fixed-effects method of Mantel-Haenszel if no heterogeneity between studies exists. Despite the similarities founded in a number of loci, the Woolf test reported that the contributions of ENPP1 and ACE loci in T2D risk are dependent on the geographic origin of concerned groups and this heterogeneity could be attributed not only, to the variable contribution of the variant in T2D risk, but also to diversities of genetic background between tested groups. Interestingly, observed heterogeneity highlighted founding concerning Y chromosome and the mitochondrial DNA about genetic structure of Tunisian population and proves once again that Tunisians, like the north- Africans, are a mosaic of subpopulations, with significant differences in genetic structure. In homogenous groups, we replicated the association of SNPs of TCF7L2, MTHFR, CAPN 10, TNF $\alpha$ and ACE genes with T2D risk in Tunisian population with OR ranging from 1.43 to 6.72 . However, we reported an absence of association of PPARg with T2D in Tunisian population. 


\section{INTRODUCTION}

The worldwide prevalence of type 2 diabetes (T2D) is projected to nearly double by the year 2025 (Kiberstis 2005). In the Tunisian population, the prevalence of T2D reaches $9 \%$ of adults (Bouguerra et al. 2007) and affects an increasing rate of Tunisian young people (about 10\%). Compared with the European populations, this rate is much higher and may be due to the specificity of the Tunisian lifestyle due to rapid urbanization and/or a specific genetic background.

T2D, like other complex diseases, results from a complex interaction between genetic and environmental factors (Lange et al. 2008). So far, 17 genetic loci have been convincingly associated with T2D risk (Florez 2008). Replication is a challenging but necessary step to validate new disease susceptibility genetic variants (Hirschhorn et al. 2002). Initial efforts to identify T2D susceptibility genes favored the genome-wide linkage approach and candidate gene association studies (Lange et al. 2008). Few common polymorphisms have been widely replicated in populations of different ethnic descents. Association studies performed on Tunisian population have indeed not been consistently replicated. Although at-risk for T2D in the European population and other ethnic descents, some of studied polymorphisms seem not to be a major contributor to T2D susceptibility in the Tunisian population (Bouhaha et al. 2008, 2010, Ouederni et al. 2009).This absence of association has been usually attributed to the modest sample size of studied cohorts. However, Tunisian population appears to be a mosaic of subpopulations; each one having a particular genetic background (Cherni et al. 2005). Besides, this genetic heterogeneity is reinforced by an important frequency of consanguinity (Ben M'Rad and Chalbi 2006) and the high endogamy characterizing most of regions. Therefore, the recruited groups in Tunisian studies are originated from the north, the centre or the south separately. Some of reported associations have indeed shown inconsistent results between Tunisian groups originated from different geographic areas.

In the current study, we evaluate the effect of seven polymorphisms in the following genes ; PPARg ( Pro12Ala), TNFa (-308A/G), ENPP1(K121Q), TCF7L2(rs7903146 C/T), MTHFR(677 C/T), ACE(I/D) and CAPN1O(3R/2R) on T2D risk in a meta-analysis combining data of previous studies performed in Tunisian populations from the north, the centre or the south of the country (Bouhaha et al. 2008, 2010a, 2010b , Ouederni et al. 2009a, 2009b, Zouari et al. 2004, 2005, Mohamed et al. 2007, Ezzidi I et al. 2009, 2010a, 2010b, Mtiraoui et al. 2007, Mehri et al. 2010a, 2010b, Baroudi et al. 2009, Arfa et al. 2008). 


\section{SEARCH STRATEGY AND DATA COLLECTION}

\section{Data collection}

A PubMed search up to April 2011, using "genetic susceptibility to type 2 diabetes in Tunisia" or "genes of diabetes in Tunisia" or "genes polymorphism and type 2 diabetes in Tunisia" or "genes, ethnicity, type 2 diabetes, Tunisia" as key words, was performed. The references of all computer-identified publications were searched for additional studies. The PubMed option "Related Articles" was used to search for potentially relevant articles. Reference lists in retrieved articles were also screened. Searching was performed in duplicate by two independent reviewers (BERHOUMA.R and KOUIDHI.S). Without any language restriction, we only selected published manuscripts (including their online supporting materials). We performed a literature review on articles concerning genetic susceptibility to T2D in Tunisian population. Only the studies with complete data on comparison of genotypic frequencies of studied polymorphisms between diabetic patients and controls were selected. The articles with incomplete data were not included in our meta-analysis. The aim of our meta-analysis was to compare the association of different genes variant with $\mathrm{T} 2 \mathrm{D}$ in populations originating from the north, the centre and the south of Tunisia in order to identify homogenous Tunisian populations and to assess for any association of the studied variant with T2D in the pooled sample. Thus, our meta-analysis contributes to have a definite conclusion about T2D-association genes in Tunisian population.

We found 34 published articles but only 13 with completed information were used in our meta-analysis. These studies have been interested in studied the same genes variants in Tunisian cohorts differing by their geographic origins.

Genes variants studied in cohorts originating from different Tunisian areas are: PPARg ( Pro12Ala), TNFa (308A/G), ENPP1(K121Q), TCF7L2(rs7903146 C/T), MTHFR(677 C /T), ACE (I/D), CAPN $10(3 R / 2 R)$. Variants studied in only one Tunisian cohort were not included in our meta-analysis.

\section{Statistical analysis}

$\mathrm{R}$ statistics version 2.12.1 software was used to estimate the heterogeneity between studies. Pooled ORs were computed by the fixed-effects method of Mantel-Haenszel (Peto's method) if no heterogeneity between studies exists. To explain the heterogeneity origin we used SPSS. 11 software. 


\section{RESULTS}

Table 1 summarized the data collected from 13 published articles and included in our meta-analysis. Confrontation of reported results found in different Tunisian cohorts showed inconsistent associations with T2D of studied polymorphisms in the seven concerned genes.

\section{PPARg ( Pro12Ala) polymorphism and type 2 diabetes}

Three studies on PPAR Pro12Ala polymorphism performed in Tunisian cohorts originated from the north and the centre did not show any association with T2D. No genetic heterogeneity on PPARg locus was significantly observed between the three tested Tunisian populations originated from the north and the centre $\left(\mathrm{P}_{\text {Woolf test }}=\right.$ 0.94) (Table 2). When combining data, our meta-analysis comprised 817 T2D cases and 907 control subjects. A Mantel-Haenszel procedure was then performed to provide a pooled OR of $1.25[0.93-1.67]\left(\mathrm{P}_{\text {-additive }}=0.14\right)$ confirming the absence of association of PPARg with T2D in Tunisian population.

\section{ENPP1(K121Q) polymorphism and type 2 diabetes}

Two studies investigated the $K 121 Q$ polymorphism of ENNP1 gene were performed on Tunisian cohorts, one originated from the north and the second was in the centre of the country. Under the additive model, the odds ratios $(\mathrm{OR})$ for T2D were $1.96(95 \% \mathrm{CI}:[1.15-3.36] P=0.008)$ and $0.86(95 \% \mathrm{CI}:[0.67-1.12](P=0.24)$ in the Northern and Central Tunisian populations, respectively (Table I). A significant genetic heterogeneity at ENPPI locus was detected between the two populations $\left(\mathrm{P}_{\text {Woolf test }}=0.004\right)($ Table 2$)$. In order to identify the causative factors of heterogeneity, we compared the MAF of normoglycemic subjects and those of diabetic patients originating from the two Tunisian localities (Table 3). Significant differences were detected only between the MAF of diabetic patients at loci ENPP1 suggesting that the contribution of the variant in T2D risk is depending on the lifestyle and the environmental factors which seem to be different between concerned localities.

\section{TCF7L2 (rs7903146 C/T), TNFa(-308A/G), and MTHFR (677 C>T) variants and type 2 diabetes}

In these cases, inconsistent results were reported about the implication of polymorphisms on $T C F 7 L 2, T N F \alpha$ and MTHFR in T2D susceptibility. Nevertheless, no genetic heterogeneity on TCF7L2, TNF $\alpha$ and MTHFR loci was significantly observed between the tested Tunisian populations, when the Woolf test was performed $\left(\mathrm{P}_{\text {Woolf }}\right.$ test $=0.22,0.24,0.30$ respectively) (Table 2). The Mantel-Haenszel procedure was performed to provide pooled OR of $1.74,95 \% \mathrm{CI}[1.29-2.34]\left(\mathrm{P}_{\text {-additive }}=0.0002\right)$ for TCF7L2 SNP, 0.69, 95\%CI[0.52-0.91) $\left(\mathrm{P}_{\text {-additive }}=0.01\right)$ 
for $T N F \alpha$ polymorphism and 2.55, 95\%CI[1.71-3.80] $\left(\mathrm{P}_{\text {-additive }}<0.0001\right)$ for $M T H F R$ variant. These results underlined the implication of the three variants in T2D risk in Tunisian population.

\section{ACE (I/D) polymorphism and type 2 diabetes}

The $I / D$ variant of $A C E$ gene has been the object of investigation in Tunisian populations originating from the north and the south of the country. Besides, in the south three different cohorts were defined; Arabs and Berbers of Djerba island and the urban population of Sfax. Reported results suggested that the $I / D A C E$ SNP provides a protector effect against T2D. However, the same variant seems not to be associated with T2D risk in the northern Tunisian population (Table 1). Observed results were confirmed by the heterogeneity tests performed on Arabs and Berbers of Djerba $\left(\mathrm{P}_{\text {Woolf test }}=0.43\right)$, Jerbian and Sfaxian groups $\left(\mathrm{P}_{\text {Woolf test }}=0.67\right)$. No heterogeneity was observed between the three southern Tunisian populations for $A C E$ gene. The Mantel-Haenszel procedure provided a pooled OR of $0.14,95 \% \mathrm{CI}[0.08-0.26]\left(\mathrm{P}_{\text {-additive }}<0.0001\right)$.

We reported a significant genetic heterogeneity $\left(\mathrm{P}_{\text {Woolf test }}=0.0008\right)$ when considering the northern and all of the southern cohorts. Otherwise, when comparing the three southern Tunisian populations separately with the northern one, we detected that only Arabs of Djerba and Sfaxian populations were significantly heterogeneous (P Woolf test $=0.03, \mathrm{P}_{\text {Woolf test }}=0.01$ respectively). This heterogeneity could be attributed not only to differences in genetic structure of concerned groups but also to the variable contribution of the variant to T2D risk in interaction with environmental factors (table 3).

On the other hand, Berbers and the northern Tunisian population seems to be genetically homogeneous at ACE locus $\left(\mathrm{P}_{\text {Woolf test }}=0.26\right)$. The Mantel-Haenszel test performed on these last homogeneous cohorts provided a pooled OR of $0.46,95 \% \mathrm{CI}[0.22-0.97]\left(\mathrm{P}_{\text {-additive }}=0.058\right)$ suggesting a trend of association of $I / D A C E$ polymorphism with T2D.

\section{CAPN $10(3 R / 2 R)$ polymorphism and type 2 diabetes}

$C A P N 103 R / 2 R$ polymorphism was investigated in three Tunisian populations Arabs, Berbers of Djerba, and a cohort of Tunisians originating from the north, the centre, and the south, however reported results have been discordant. In return, the heterogeneity test did not show any significant genetic difference between the considered groups. The Mantel-Haenszel test suggested an absence of association of the CAPN 10 variant with T2D susceptibility $(\mathrm{p}=0.45)$ and provided a pooled OR of $1.35,95 \% \mathrm{CI}[0.67-2.75]$. However, the pooled OR of 
all Tunisian tested cohorts was of $1.61,95 \% \mathrm{CI}[1.23-2.11]$ with a $\mathrm{p}$ value of 0.0006 underlining the implication of CAPN10 polymorphism in the increase of T2D risk in Tunisians.

\section{DISCUSSION}

Important advances in the genetics of T2D have come with the completion of GWAS. In the past three years, GWAS for human T2D from several European populations have revealed 25 confirmed T2D-associated loci, providing new insights into the etiological mechanisms of T2D development. In Tunisia, A few genes have been investigated in association with T2D risk and association studies have been performed only in limited sample size cohorts, usually, originating from the same geographic area (namely from the north, the centre or the south). Thus, some studies replicated T2D association; however, some others failed to identify significant association, suggesting variability in the contribution of number of variants to T2D risk. To investigate this issue, we performed a comprehensive meta-analysis for the eligible studies. Our meta-analysis concerned the effect of seven polymorphisms; PPARg (Pro12Ala), TNFa (-308A/G), ENPP1(K121Q), TCF7L2(rs7903146 C/T), $\operatorname{MTHFR}(C 677 T), A C E(I / D)$, and $C A P N 10(3 R / 2 R)$ on T2D susceptibility, previously studied in different Tunisian cohorts. However, reported results were inconsistent for a number of variants (Table 1).

No heterogeneity was detected for six genetic markers between Tunisian groups originated from several localities. These loci remained stable in diverse Tunisian populations, indicating that these sub-populations have common features and allowed to focus on association-T2D studies in large Tunisian sample size. To investigate this issue, we performed our meta-analysis pooling cohorts of homogenous groups. Thus, we replicated the association of SNPs of TCF7L2, MTHFR, CAPN 10, TNF $\alpha$ and ACE genes with T2D risk in Tunisian population with an OR ranging from 1.43 to 6.72 ( Figure 1). Our meta-analysis confirms the strong evidence of association of TCF7L2 gene with T2D reported previously in several populations involving Caucasians, North Europeans, East Asians, Indians, and Africans (Tong et al. 2009). Otherwise, the association of SNP rs7903146 in TCF7L2 with T2D is now well established as the strongest common genetic determinant of T2D yet described. Concerning others genes polymorphisms, inconsistent results through ethnic groups were reported. MTHFR variant was particularly associated with diabetic complications notably nephropathy and retinopathy (Zintzaras et al. 2005, 2007, Movva et al. 2010). A recent meta-analysis performed by Niu W et al. (2010) demonstrated that ACE D allele was significantly associated with an increased risk for T2D and this effect appeared to be inherited additively. Moreover, subgroup analyses further narrowed down this conclusion by showing that the 
risk effect of D allele was more obvious for population-based studies and among populations from Africa and Europe ancestries while its role was significantly weakened in Asian replications. The same heterogeneities were observed in studies investigated the effect of CAPN10 and TNF $\alpha$ on T2D risk (Tsuchiya et al. 2006, Boraska et al. 2010, Feng et al. 2009).

Our results about the Pro 12Ala of PPAR variant confirmed those reported previously (Zeggini et al. 2005; Muller et al. 2003), and did not favor a significant role of this variant in T2D risk in the Tunisian population. Conflicting results have been reported regarding whether the PPARG-Pro12Ala polymorphism played a role in the risk of T2D. Interestingly, Ludovico et al. (2007) reported in their meta-analysis of 42,910 subjects that the role played by the Pro12Ala variant on T2D risk was very heterogeneous, and this was explained by an effect of BMI which interacted strongly with T2D susceptibility. More recently a HuGE association review involved an updated meta-analysis of the relation between the PPAR 2 Pro12Ala polymorphism and T2D among 32,849 cases and 47,456 controls in 60 studies confirms the association of the variant with a reduction in T2D risk (odds ratio $=0.86,95 \%$ CI: $0.81,0.90)($ Gouda et al. 2010). This reported discrepancy has been attributed, not only to differences in BMI (Masud and Ye 2003, Ghoussaini et al. 2005) but also to a complex interaction of the Pro12Ala polymorphism with environmental factors (such as the ratio of dietary unsaturated fatty acids to saturated fatty acids) (Luan et al. 2001) with genetic factors such as polymorphic mutations in other genes (Hsueh et al. 2001).

On the other hand, the heterogeneity test confirmed the diversities observed in T2D associations for ENPP1 and $A C E$ variants. In fact, the contributions of these loci to T2D risk were dependent on the geographic origin of concerned groups. This heterogeneity could be explained not only by the diversity of genetic background which appeared for $A C E$ between normoglycemic subjects originated from different regions, but also by the variable contribution of the variant in T2D risk because of the diversity of lifestyles into the tested subpopulations. Interestingly, the significant difference detected between normoglycemic subjects (originated from Sfax and Grand Tunis) at $A C E$ locus highlighted founding about genetic structure of Tunisian population. Previous reports describing the history of Tunisian's origin and using several genetic markers analysis have shown that Tunisian population, like the north- Africans, is a mosaic of subpopulations, with significant differences in genetic structure (Cherni et al. 2005). This genetic heterogeneity is reinforced by an important consanguinity rate (Ben M'Rad and Chalbi 2006) and regional endogamy that could lead to isolated status. Hence, heterogeneity shown by woolf test for ACE locus seems to be related at least partly to fragmentation found in Tunisian population. Moreover, divergent results of association were detected at ENPPI and ACE loci, whereas a similar frequency of 
the studied polymorphisms in normoglycemic subjects observed in both studies. This could be explained by a modest contribution of variants to the risk of T2D in Tunisians population, and also by the interaction with BMI, nutritional and environmental factors in modulating T2D risk, as previously reported (Meyre et al. 2005, Grarup et al. 2006, Cauchi et al. 2008). Indeed, Tunisian sub-population lifestyle contributes significantly to diversify environmental factors interacting with genetic factors affecting T2D susceptibility. As previously reported, Arabs of Djerba have sedentary habits and excessive sugar intake, compared to neighboring Berbers (Baroudi et al. 2010). In Grand Tunis, people life style's is more westernized with reduced physical activity and excessive calorie intake in foods, comparing with people living in other Tunisian regions. Thus, in two different Tunisian regions, there is not the same combination of environmental and genetic factors predisposing to T2D. In such conditions, the contribution of a number of variants changes with ethnicity.

As a matter of fact, T2D appears to be composed of subtypes where genetic susceptibility is strongly associated with environmental factors at one end of the spectrum, and highly genetic forms at the other end. Thus, there are several possible interactions between gene and gene or between gene and environmental factors. These hypothetical interactions and their specific effects on $\mathrm{T} 2 \mathrm{D}$, as well as functional analyses, will be required to further elucidate the role of gene variations in the pathogenesis of T2D and very large samples are needed.

In conclusion, the current study is the first meta-analysis interested in T2D-associated polymorphisms, performed on cohorts' compound of populations originating from different Tunisian regions. Although differing by their geographic origins and lifestyles, these populations appeared to be genetically homogeneous at a number of loci which allowed us to replicate the implication of TCF7L2, MTHFR, CAPN 10, TNFa and ACE polymorphisms in T2D susceptibility in Tunisia. Whereas, heterogeneity observed for other loci highlighted founding about genetic structure of Tunisian population and proves once again that Tunisians, like the northAfricans, are a mosaic of subpopulations, with significant differences in genetic structure (Cherni et al. 2005). Only, genetic differences in Tunisian populations were previously reported when studying the Y chromosome and the mitochondrial DNA, this is the first study reporting genetic differences in other loci.

Our study underlines the importance of Woolf test which should be performed in all association studies involving populations originating from different localities. Otherwise, further GWA studies in Tunisian populations are required to further define the genetic and lifestyle determinants of T2D, which will be very useful to prevent this metabolic disorder. 


\section{REFERENCES}

Arfa, I., Abid, A., Nouira, S., Elloumi-Zghal, H., Malouche, D., Mannai, I., Zorgati M.M., Ben-Alaya, N., Rebai, A., Zouari, B., Ben-Ammar, S., Ben-Rayana, M.C., Hmida, S., Blousa-Chabchoub, S. \& Abdelhak, S. 2008. Lack of association between the angiotensin-converting enzyme gene (I/D) polymorphism and diabetic nephropathy in Tunisian type 2 diabetic patients. J Renin Angiotensin Aldosterone Syst, 9(1): 32-6.

Baroudi, T., Bouhaha, R., Moran-Moguel, C., Sanchez-Corona, J., Ben-Maiz, H., Kammoun, A.H. \& BenammarElgaaied, A. 2009. Association of the insertion/deletion polymorphism of the angiotensin-converting enzyme gene with type 2 diabetes in two ethnic groups of Jerba Island in Tunisia. J Renin Angiotensin Aldosterone Syst, 10(1): $35-40$.

Baroudi, T., Maiz, H.B., Abid, H.K., Benammar-Elgaaied, A. \& Alouane, L.T. 2010. Dietary intakes of essential nutrients among Arab and Berber ethnic groups on rural Tunisian island. Nutrition, 26(1) :75-81.

Ben M'Rad, L. \& Chalbi, N. 2006. Milieu de résidence origine des conjoints et consanguinité en Tunisie. Antropo, 12: 63-71. www.didac.ehu.es/antropo

Boraska, V., Rayner, N.W., Groves, C.J., Frayling, T.M., Diakite, M., Rockett, K.A., Kwiatkowski, D.P., DayWilliams, A.G., McCarthy, M.I. \& Zeggini, E. 2010. Large-scale association analysis of TNF/LTA gene region polymorphisms in type 2 diabetes. B MC Med Genet, 6 :11-69.

Bouguerra, R., Alberti, H., Salem, L.B., Rayana, C.B., Atti, J.E., Gaigi, S., Slama, C.B., Zouari, B\& Alberti, K. 2007. The global diabetes pandemic: the Tunisian experience. Eur J Clin Nutr, 61(2) :160-5.

Bouhaha, R., Baroudi, T., Ennafaa, H., Vaillant, E., Abid, H., Sassi, R., Vatin, V., Froguel, P., Gaaied, A.B., Meyre, D., Vaxillaire, M. 2010a. Study of TNFalpha -308G/A and IL6 -174G/C polymorphisms in type 2 diabetes and obesity risk in the Tunisian population. Clin Biochem, 43(6): 549-52.

Bouhaha, R., Choquet, H., Meyre, D., Abid, K.H., Ennafaa, H., Baroudi, T., Sassi, R., Vaxillaire , M., Elgaaied, A., Froguel, P. \& Cauchi, S. 2010b. TCF7L2 is associated with type 2 diabetes in non obese individuals from Tunisia. Pathol Biol (Paris), 58(6): 426-9.

Bouhaha, R., Meyre, D., Kamoun, H.A., Ennafaa, H., Vaillant, E., Sassi, R., Baroudi, T., Vatin, V., Froguel, P., Elgaaied, A., Vaxillaire, M. 2008. Effect of ENPP1/PC-1-K121Q and PPARgamma-Pro12Ala polymorphisms on the genetic susceptibility to T2D in the Tunisian population. Diabetes Res Clin Pract, 81(3): 278-83.

Cauchi, S., Nead, K.T., Choquet, H., Horber, F., Potoczna, N., Balkau, B., Marre, M., Charpentier, G., Froguel, P., Meyre, D. 2008. The genetic susceptibility to type 2 diabetes may be modulated by obesity status: implications for association studies. BMC Med Genet, 9:45. 
Cherni, L., Loueslati, B.Y., Pereira, L. 2005. Female gene pools of Berber and Arab neighboring communities in central Tunisia: microstructure of mtDNA variation in North Africa. Hum Biol, 77 : 61-70.

Ezzidi, I., Mtiraoui, N., Cauchi, S., Vaillant, E., Dechaume, A., Chaieb, M., Kacem, M., Almawi, W.Y., Froguel, P., Mahjoub, T. \& Vaxillaire, M. 2009. Contribution of type 2 diabetes associated loci in the Arabic population from Tunisia: a case-control study. BMC Med Genet, 15: 10-33.

Ezzidi, I., Mtiraoui, N., Nemr, R., Kacem, M., Al-Khateeb, G.M., Mahjoub, T. \& Almawi, W.Y. 2010a. Variants within the calpain-10 gene and relationships with type 2 diabetes (T2DM) and T2DM-related traits among Tunisian Arabs. Diabetes Metab, 36(5): 357-62.

Ezzidi, I., Turki, A., Messaoudi, S., Chaieb, M., Kacem, M., Al-Khateeb, G.M., Mahjoub, T., Almawi, W.Y. \& Mtiraoui, N. 2010b. Common polymorphisms of calpain-10 and the risk of Type 2 Diabetes in a Tunisian Arab population: a case-control study. BMC Med Genet, 15: 71-75.

Feng, R., Li, Y., Zhao, D., Wang, C., Niu, Y., Sun, C. 2009. Lack of association between TNF 238 G/A polymorphism and type 2 diabetes: a meta-analysis. Acta Diabetol, 46(4) : 339-43.

Florez, J.C. 2008. The genetics of type 2 diabetes: a realistic appraisal circa. J Clin Endocrinol Metab, 93: 46334642 .

Ghoussaini,M., Meyre, D., Lobbens, S., Charpentier, G., Clément, K. \& Charles, M. A. 2005. Implication of the Pro12Ala polymorphism of the PPAR-gamma 2 gene in T2D and obesity in the French population. BMC Medical Genetics: 6-11.

Gouda, H.N., Sagoo, G.S., Harding, A.H., Yates, J., Sandhu, M.S. \& Higgins, J.P. 2010. The association between the peroxisome proliferator-activated receptor-gamma2 (PPARG2) Pro12Ala gene variant and type 2 diabetes mellitus: a HuGE review and meta-analysis. Am J Epidemiol, 171(6): 645-55.

Grarup, N., Urhammer, S.A., Ek, J., Albrechtsen, A., Glumer, C., Borch- Johnsen, K., Jorgensen, T., Hansen, T. \& Pedersen, O. 2006. Studies of the relationship between the ENPP1 K121Q polymorphism and type 2 diabetes, insulin resistance and obesity in 7,333 Danish white subjects. Diabetologia, 49(9) : 2097-2104.

Hirschhorn, J.N., Lohmueller, K., Byrne, E. \& Hirschhorn, K. 2002. A comprehensive review of genetic association studies. Genet Med, 4: 45-61.

Hsueh,W.C., Cole, S. A., Shuldiner, A.R. 2001. Interactions between variants in the $\beta 3$-adrenergic receptor and peroxisome proliferator-activated receptor- $\gamma 2$ genes and obesity. Diabetes, 24 : 672-677.

Kiberstis, P.A. 2005. A surfeit of suspects. Science, 307- 369.

Lange, E.M., Sun, J., Lange, L.A., Zheng, S.L., Duggan, D., Carpten, J.D., Gronberg, H., Isaacs, W.B., Xu, J. \& 
Chang, B.L. 2008. Family-based samples can play an important role in genetic association studies. Cancer Epidemiol Biomarkers Prev, 17: 2208-2214.

Luan, J., Browne, P.O. \& Harding, A.H. 2001. Evidence for gene-nutrient interaction at the PPARc locus. Diabetes, 50(3): 686-689.

Ludovico, O., Pellegrini, F., Di-Paola, R., Minenna, A., Mastroianno, S., Cardellini, M., Marini, M.A., Andreozzi, F., Vaccaro, O., Sesti, G. \& Trischitta, V. 2007. Heterogeneous effect of peroxisome proliferator-activated receptor gamma2 Ala12 variant on type 2 diabetes risk. Obesity (Silver Spring), 15 : 1076-1081.

Masud, S. \& Ye, S. 2003. Effect of the peroxisome proliferator activated receptor-c gene Pro12Ala variant on body mass index: a metaanalysis. J Med Genet, 40(10):773-780.

Mehri, S., Koubaa, N., Nakbi, A., Hammami, S., Chaaba, R., Mahjoub, S., Zouari, B., Abid, M., Ben-Arab, S., Baudin, B., Hammami, M. 2010a. Relationship between genetic polymorphisms of angiotensin-converting enzyme and methylenetetrahydrofolate reductase as risk factors for type 2 diabetes in Tunisian patients. Clin Biochem, $43(3): 259-66$.

Mehri, S., Koubaa, N., Hammami, S., Mahjoub, S., Chaaba, R., Nakbi, A., Zouari, B., Abid, M., Ben-Arab, S., Baudin, B., Hammami, M. 2010b. Genotypic interactions of renin-angiotensin system genes with diabetes type 2 in a Tunisian population. Life Sci, 3, 87(1-2): 49-54.

Meyre, D., Bouatia-Naji, N., Tounian, A., Samson, C., Lecoeur, C., Vatin, V., Ghoussaini, M., Wachter, C., Hercberg, S., Charpentier, G. 2005. Variants of ENPP1 are associated with childhood and adult obesity and increase the risk of glucose intolerance and type 2 diabetes. Nat Genet, 37(8): 863-867.

Mohamed, M.B., Mtiraoui, N., Ezzidi, I., Chaieb, M., Mahjoub, T. \& Almawi, W.Y. 2007. Association of the peroxisome proliferator-activated receptor-gamma2 Pro12Ala but not the C1431T gene variants with lower body mass index in Type 2 diabetes. J. Endocrinol Invest, 30(11): 937-43.

Movva, S., Alluri, R.V., Venkatasubramanian, S., Vedicherla, B., Vattam, K.K., Ahuja, Y.R. \& Hasan, Q. 2011. Association of methylene tetrahydrofolate reductase C677T genotype with type 2 diabetes mellitus patients with and without renal complications. Genet Test Mol Biomarkers, 15(4) : 257-61.

Mtiraoui, N., Ezzidi, I., Chaieb, M., Marmouche, H., Aouni, Z., Chaieb, A., Mahjoub, T., Vaxillaire, M. \& Almawi W.Y. 2007. MTHFR C677T and A1298C gene polymorphisms and hyperhomocysteinemia as risk factors of diabetic nephropathy in type 2 diabetes patients. Diabetes Res Clin Pract, 75(1): 99-106.

Muller, Y.L., Bogardus, C., Beamer, B.A., Shuldiner, A.R. \& Baier, .LJ. 2003. A functional variant in the peroxisome proliferatoractivated receptor gamma2 promoter is associated with predictors of obesity and type 2 
diabetes in Pima Indians. Diabetes, 52: 1864-1871.

Niu, W., Qi, Y., Gao, P. \& Zhu, D. 2010. Angiotensin converting enzyme D allele is associated with an increased risk of type 2 diabetes: evidence from a meta-analysis. Endocr J, 57(5) : 431-8.

Ouederni, T.B., Sanchez-Corona, J., Flores-Martinez, S.E., Ben-Maiz, H., Skhiri, H.A., Abid, H.K. \& BenammarElgaaied, A. 2009a. The G1057D polymorphism of IRS-2 gene is not associated with type 2 diabetes and obese patients among ethnic groups in Tunisian population. Clin Biochem, 42: 1169-73.

Ouederni, T.B., Sanchez-Corona, J., Skhiri, H.A., Maiz, H.B., Abid, H.K., Benammar-Elgaaied, A. 2009b. Study of association of the SNP19 polymorphism of calpain 10 gene with type 2 diabetes in ethnic sub-groups of the Tunisian population: gene-environment interaction . Ann Biol Clin (Paris), 67(2): 171-6.

Tong, Y., Lin, Y., Zhang, Y., Yang, J., Zhang, Y., Liu, H. \& Zhang, B. 2009. Association between TCF7L2 gene polymorphisms and susceptibility to type 2 diabetes mellitus: a large Human Genome Epidemiology (HuGE) review and meta-analysis. BMC Med Genet, 19:10-15.

Tsuchiya, T., Schwarz, P.E., Bosque-Plata, L.D., Geoffrey Hayes, M., Dina, C., Froguel, P., Wayne Towers, G., Fischer, S., Temelkova-Kurktschiev, T., Rietzsch, H., Graessler, J., Vcelák, J., Palyzová, D., Selisko, T., Bendlová, B., Schulze, J., Julius, U., Hanefeld, M., Weedon, M.N., Evans, J.C., Frayling, T.M., Hattersley, A.T., OrhoMelander, M., Groop, L., Malecki, M.T., Hansen, T., Pedersen, O., Fingerlin, T.E., Boehnke, M., Hanis, C.L., Cox, N.J. \& Bell, G.I. 2006. Association of the calpain-10 gene with type 2 diabetes in Europeans: results of pooled and meta-analyses. Mol Genet Metab, 89(1-2): 174-84.

Zeggini, E., Parkinson, J.R. \& Halford, S. 2005. Examining the relationships between the Pro12Ala variant in PPARG and type 2 diabetes-related traits in UK samples. Diabet Med, 22: 1696-1700.

Zintzaras, E., Chatzoulis, D.Z., Karabatsas, C.H., Stefanidis, I. 2005. The relationship between C677T methylenetetrahydrofolate reductase gene polymorphism and retinopathy in type 2 diabetes: a meta-analysis. $J$ Hum Genet, 50(6) : 267-75.

Zintzaras, E., Uhlig, K., Koukoulis, G.N., Papathanasiou, A.A., Stefanidis, I. 2007. Methylenetetrahydrofolate reductase gene polymorphism as a risk factor for diabetic nephropathy: a meta-analysis. J Hum Genet, 52(11): 88190.

Zouari, B.K., Chouchane, L., Jellouli, K., Chérif, S., Haddad, S., Gabbouj, S. \& Danguir, J. 2004. Polymorphism of stress protein HSP70-2 gene in Tunisians: susceptibility implications in type 2 diabetes and obesity. Diabetes Metab, 30(2) : 175-80.

Zouari, B.K., Chouchane, L., Jellouli, K., Chérif, S., Haddad, S., Gabbouj, S. \& Danguir, J. 2005. The peroxisome 
proliferator activated receptorgamma2 (PPARgamma2) Pro12Ala variant: lack of association with type 2 diabetes in obese and non obese Tunisian patients. Diabetes Metab, 31(2): 119-23. 
Table 1: T2D-association studies in several Tunisian regions( Rs ID: $r$ s identity, NG: normoglycemic, T2D: type 2 diabetic patients, MAF: Minor allele frequency, Add: Genetic additive model: 1/1 vs. 1/2 or 2/2 genotypes, Dom: Genetic dominant model: 1/1 vs. 1/2 + 2/2 genotypes, 95\%CI: confidence intervalle.)

\begin{tabular}{|c|c|c|c|c|c|c|c|c|c|c|c|c|}
\hline GENE & SNP & rs-ID & ALLELE & TESTED POPULATION & $\begin{array}{l}\text { CORRESPENDANT } \\
\text { GEOGRAPHIC } \\
\text { LOCALISATION }\end{array}$ & STUDIES & SAMPLE SIZE & $\begin{array}{c}\text { MAF\% of } \\
\text { NG }\end{array}$ & $\begin{array}{c}\text { MAF\% of } \\
\text { T2D }\end{array}$ & $\begin{array}{c}\text { INHERITANCE } \\
\text { MODEL }\end{array}$ & $P$ value & $\mathrm{OR}, 95 \% \mathrm{Cl}$ \\
\hline \multirow[t]{5}{*}{ PPARg } & Pro12Ala & rs1801282 & Pro/Ala & Grand Tunis & North of Tunisia & BOUHAHA et al. 2008 & $261 \mathrm{NG} / 84 \mathrm{~T} 2 \mathrm{D}$ & $5.74 \%$ & $17.85 \%$ & add & 0.16 & $1.66(0.76-3.59)$ \\
\hline & & & & & & & & & & dom & 0.14 & $1.66(0.78-3.50)$ \\
\hline & & & & Grand Tunis & North of Tunisia & BOUASSIDA et al. 2005 & $246 \mathrm{NG} / 242 \mathrm{~T} 2 \mathrm{D}$ & $5.48 \%$ & $5 \%$ & add & 0.62 & $1.12(0.6-2.11)$ \\
\hline & & & & Sousse & Center of Tunisia & BEN HADJ M et al, 2007 & 400NG/491T2D & $7 \%$ & $8 \%$ & add & 0.25 & $1.25(0.84-1.85)$ \\
\hline & & & & & & & & & & dom & 0.20 & $1.28(0.86-1.89)$ \\
\hline \multirow[t]{4}{*}{ ENPP1 } & K121Q & rs1044498 & $\mathrm{K} / \mathrm{Q}$ & Grand Tunis & North of Tunisia & BOUHAHA et al. 2008 & 243NG/110T2D & $35.18 \%$ & $47.72 \%$ & add & 0.008 & $1.96(1.15-3.36)$ \\
\hline & & & & & & & & & & dom & 0.009 & $1.89(1.13-3.15)$ \\
\hline & & & & Centre of Tunisia & Centre of Tunisia & EZZIDI et al. 2009 & 499NG/809T2D & $33 \%$ & $31 \%$ & add & 0.24 & $0.86(0.67-1.12)$ \\
\hline & & & & & & & & & & dom & 0.16 & $0.84(0.66-1.07)$ \\
\hline \multirow[t]{5}{*}{ TCF7L2 } & $C / T$ & rs7903146 & $C / T$ & Grand Tunis & North of Tunisia & BOUHAHA et al. 2010 & $172 N G / 34 T 2 D$ & $41.5 \%$ & $47 \%$ & add & 0.02 & $3.24(1.10-9.53)$ \\
\hline & & & & & & & & & & dom & 0.12 & $3.47(0.67-17.99)$ \\
\hline & & & & Centre of Tunisia & Centre of Tunisia & EZZIDI et al. 2009 & $511 N G / 863 T 2 D$ & $42 \%$ & $48 \%$ & add & 0.002 & $1.56(1.13-2.16)$ \\
\hline & & & & & & & & & & dom & 0.02 & $1.33(1.04-1.70)$ \\
\hline & $(-308)$ & & & & & & & 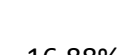 & 1470 & & & \\
\hline \multirow[t]{3}{*}{ TNF $\alpha$} & G/A & rs1800629 & G/A & Grand Tunis & North of Tunisia & BOUHAHA et al. 2010 & 299NG/195T2D & & & add & 0.81 & $0.83(0.54-1.27)$ \\
\hline & & & & & & & & & & dom & 0.08 & $0.82(0.54-1.25)$ \\
\hline & & & & Grand Tunis & North of Tunisia & BOUASSIDAet al. 2004 & $274 N G / 280 T 2 D$ & $18 \%$ & $21 \%$ & add & 0.003 & $0.58(0.39-0.85)$ \\
\hline
\end{tabular}




\begin{tabular}{|c|c|c|c|c|c|c|c|c|c|c|c|c|}
\hline & & & & & & & & & & dom & 0.04 & $0.68(0.47-0.99)$ \\
\hline \multirow[t]{4}{*}{ MTHFR } & C677T & & $C / T$ & Sousse & Centre of Tunisia & MTIRAOUI et al.2007 & $400 \mathrm{NG} / 360 \mathrm{~T} 2 \mathrm{D}$ & $21 \%$ & $36 \%$ & add & $<0.001$ & $2.39(1.69-3.35)$ \\
\hline & & & & & & & & & & dom & $<0.001$ & $2.51(1.85-3.41)$ \\
\hline & & & & Sfax & South of Tunisia & MEHRI et al.2010 & 116NG/115T2D & $26.7 \%$ & $35 \%$ & add & 0.12 & $1.52(0.89-2.60)$ \\
\hline & & & & & & & & & & dom & 0.04 & $1.72(0.99-2.99)$ \\
\hline \multirow[t]{8}{*}{ ACE } & I/D & & I/D & Arabs of Djerba & South of Tunisia & BAROUDI et al.2009 & 70NG/102T2D & $39.29 \%$ & $14.71 \%$ & add & $<0.01$ & $0.13(0.04-0.43)$ \\
\hline & & & & & & & & & & dom & $<0.01$ & $0.24(0.12-0.50)$ \\
\hline & & & & Berbers of Djerba & South of Tunisia & BAROUDI et al.2009 & 4ONG/60T2D & $31.29 \%$ & $15 \%$ & add & $<0.01$ & $0.25(0.06-1.05)$ \\
\hline & & & & & & & & & & dom & $<0.01$ & $0.41(0.16-1.07)$ \\
\hline & & & & Sfax & South of Tunisia & MEHRI et al. 2009 & 116NG/115T2D & $43 \%$ & $30 \%$ & add & 0.0001 & $0.29(0.2-0.58)$ \\
\hline & & & & & & & & & & dom & $<0.001$ & $0.20(0.11-0.38)$ \\
\hline & & & & Grand Tunis & North of Tunisia & ARFA et al. 2008 & 103NG/141T2D & $39 \%$ & $34 \%$ & add & 0.25 & $0.62(0.25-1.53)$ \\
\hline & & & & & & & & & & dom & 0.31 & $0.77(0.44-1.33)$ \\
\hline \multirow[t]{7}{*}{ CAPN } & & & & North, centre and & & & & & & & & \\
\hline & 年 & 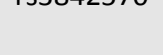 & IVI $\angle \mathrm{T}$ & south of Tunisia & & EZZIDI et al. 2010 & / 40 IV $/ 91 / 120$ & $40 \%$ & $46 \%$ & add & 0.002 & $1.61(1.20-2.18)$ \\
\hline & & & & & & & & & & dom & 0.001 & $1.43(1.15-1.77)$ \\
\hline & & & & Arabs of Djerba & South of Tunisia & BAROUDI et al. 2009 & 70NG/102T2D & $30.71 \%$ & $41.18 \%$ & add & 0.3 & $1.66(0.57-4.91)$ \\
\hline & & & & & & & & & & dom & 0.25 & $1.50(0.71-3.19)$ \\
\hline & & & & Berbers of Djerba & South of Tunisia & BAROUDI et al. 2009 & 4ONG/60T2D & $45 \%$ & $40 \%$ & add & 0.07 & $0.30(0.08-1.12)$ \\
\hline & & & & & & & & & & dom & 0.11 & $0.43(0.15-1.20)$ \\
\hline
\end{tabular}


Table 2: heterogeneity test ( $P$ values concerned the additive model of inheritance)

\begin{tabular}{|c|c|c|c|c|c|}
\hline \multirow[t]{2}{*}{ GENE } & \multirow[t]{2}{*}{ POPULATION } & \multirow{2}{*}{$\begin{array}{c}\text { WOOLF TEST } \\
\text { P VALUE } \\
\end{array}$} & \multicolumn{3}{|c|}{ HAENSZEL TEST } \\
\hline & & & $\mathbf{X} 2$ & $\mathbf{p}$ & OR, $95 \% \mathrm{Cl}$ \\
\hline \multirow[t]{2}{*}{ PPARg } & Grand Tunis/ Grand Tunis & 0.41 & 1.23 & 0.26 & $1.33(0.84-2.10)$ \\
\hline & Grand Tunis (pooled)/ Sousse & 0.94 & 2.13 & 0.14 & $1.25(0.93-1.67)$ \\
\hline ENPP1 & Grand Tunis/ Centre of Tunisia & 0.004 & & & \\
\hline TCF7L2 & Grand Tunis/ Centre of Tunisia & 0.22 & 13.36 & 0.0002 & $1.74(1.29-2.34)$ \\
\hline TNFa & Grand Tunis/ Grand Tunis & 0.24 & 6.28 & 0.01 & $0.69(0.52-0.91)$ \\
\hline MTHFR & Sousse/ Sfax & 0.30 & 21.25 & $4.01 \times 10^{-6}$ & $2.55(1.71-3.80)$ \\
\hline \multirow[t]{7}{*}{ ACE } & (Arabs / Berbers) of Djerba & 0.43 & 18.49 & $1.70 \times 10^{-5}$ & $0.16(0.07-0.39)$ \\
\hline & Arabs of Djerba / Sfax & 0.98 & 41.5 & $1.14 \times 10^{-10}$ & $0.13(0.06-0.24)$ \\
\hline & Berbers of Djerba / Sfax & 0.37 & 29.98 & $4.36 \times 10^{-8}$ & $0.15(0.08-0.30)$ \\
\hline & Arabs +Berbers of Djerba /Sfax & 0.67 & 45.82 & $1.29 \times 10^{-11}$ & $0.14(0.08-0.26)$ \\
\hline & Arabs of Djerba / Tunis & 0.03 & & & \\
\hline & Berbers of Djerba / Tunis & 0.26 & 3.58 & 0.058 & $0.46(0.22-0.97)$ \\
\hline & Tunis/Sfax & 0.01 & & & \\
\hline \multirow[t]{4}{*}{ CAPN 10} & (Arabs / Berbers) of Djerba & 0.14 & 0.45 & 0.49 & $1.35(0.67-2.75)$ \\
\hline & Arabs of Djerba / cosmopolitans & 0.69 & 13.29 & 0.0002 & $1.69(1.28-2.23)$ \\
\hline & Berbers of Djerba /cosmopolitans & 0.14 & 9.47 & 0.002 & $1.57(1.18-2.08)$ \\
\hline & $\begin{array}{c}\text { Arabs +Berbers of Djerba } \\
\text { /Cosmopolitans }\end{array}$ & 0.63 & 11.71 & 0.0006 & $1.61(1.23-2.11)$ \\
\hline
\end{tabular}


Table 3: Origins of heterogeneity at ENPP1 and ACE loci (MAF\% : Minor allele frequency, NG: Normoglycemic)

\begin{tabular}{|c|c|c|c|c|c|c|c|}
\hline GENE & $\begin{array}{c}\text { TESTED } \\
\text { POPULATION }\end{array}$ & $\begin{array}{l}\text { GEOGRAPHIC } \\
\text { LOCALISATION }\end{array}$ & MAF\% of NG & $\begin{array}{l}\text { P value of NG } \\
\text { comparison }\end{array}$ & MAF\% of T2D & $\begin{array}{l}\text { Pvalue of T2D } \\
\text { comparison }\end{array}$ & $\begin{array}{c}\text { Pvalue } \\
\text { T2Dversus } \\
\text { NG }\end{array}$ \\
\hline ENPP1 & $\begin{array}{c}\text { Grand Tunis } \\
\text { Center of Tunisia }\end{array}$ & $\begin{array}{l}\text { North of Tunisia } \\
\text { Center of Tunisia }\end{array}$ & $\left.\begin{array}{c}35,18 \% \\
33 \%\end{array}\right\}$ & 0.88 & $\left.\begin{array}{c}47,72 \% \\
31 \%\end{array}\right\}$ & $<0.001$ & $\begin{array}{c}<0.001 \\
0.14\end{array}$ \\
\hline ACE & $\begin{array}{c}\text { Arabes of Jerba } \\
\text { Grand Tunis } \\
\text { Sfax }\end{array}$ & $\begin{array}{l}\text { South of Tunisia } \\
\text { North of Tunisia } \\
\text { South of Tunisia }\end{array}$ & $\left.\begin{array}{c}39,29 \% \\
39 \% \\
43 \%\end{array}\right\}$ & $\begin{array}{c}0.64 \\
<0.001\end{array}$ & $\left.\begin{array}{cc}14,71 \% & \\
34 \% & \\
30 \% & \end{array}\right\}$ & $<0.001$ & $\begin{array}{c}<0.001 \\
0.30 \\
<0.001\end{array}$ \\
\hline
\end{tabular}


Figure 1: Estimation of odds ratios (OR) and 95\% confidence intervals (CI) of TCF7L2, MTHFR, ACE, TNF $\alpha$ and CAPN10 polymorphisms in the pooled Tunisian cohorts

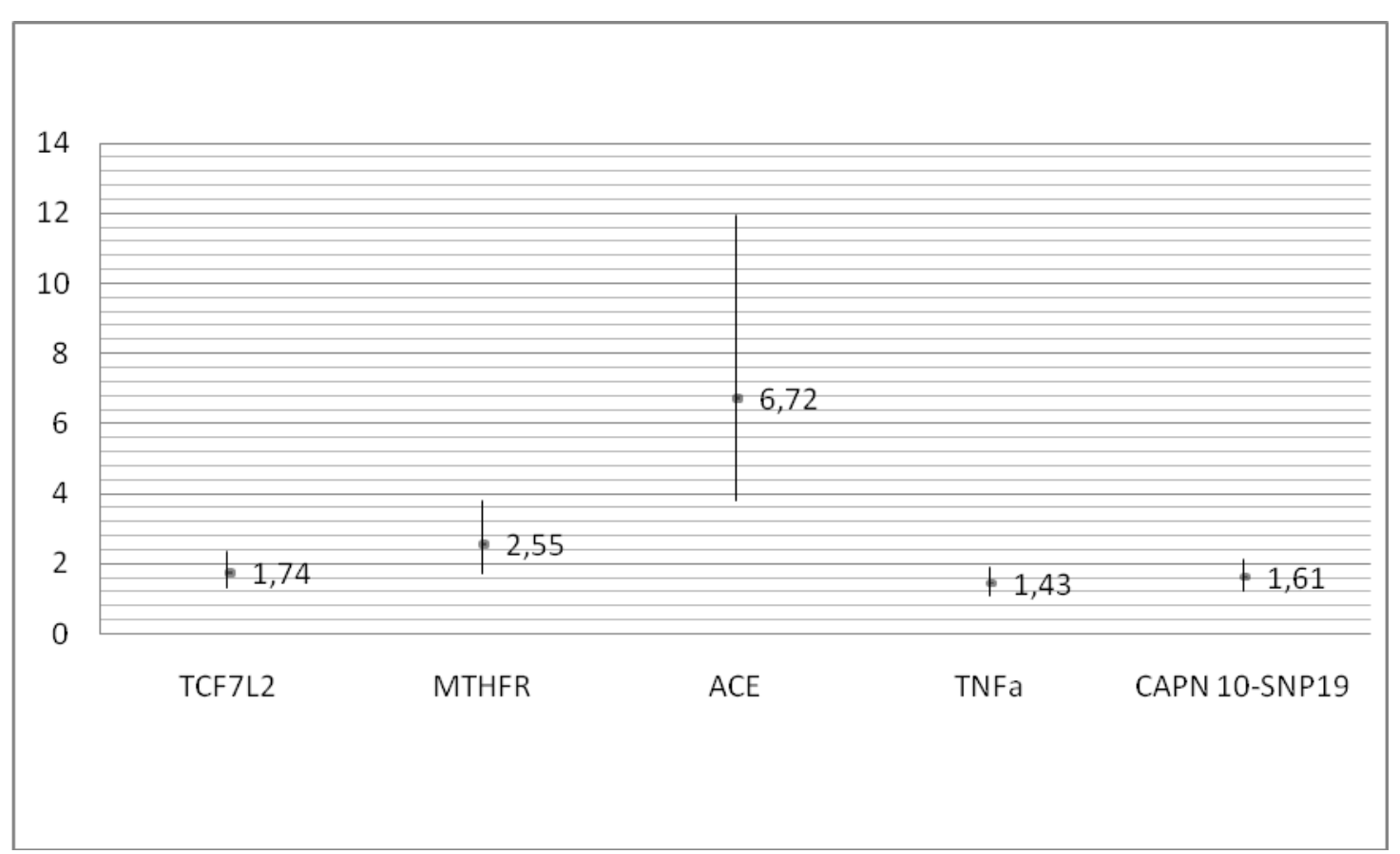

